

\title{
ORGANISATIONAL ENVIRONMENTS AND YOUNG WORKERS' ORIENTATION TO LEARN
}

\author{
Robyn Mason \\ Department of Human Resource \\ Management. \\ Massey University, Palmerston North
}

\begin{abstract}
Rapid advances in information technology, changing workplace structures and labour shortages have increased the need for emplovees to be multi-skilled, adaptable and self-directed learners. However, with an international agenda for lifelong learning and capability development there are concerns about persistent social and labour market inequities, and low levels of education and literacy of some workers. Moreover, little is known about young people 's beliefs and attitudes towards learning during their early years in the labour market. Accordingly researchers have called for the need to develop the capabilities of lower-skilled emplovees and young workers from lower socio-economic backgrounds - employees who are at risk of being overlooked in a knowledge-driven economy. This paper examines relevant international and New Zealand research and indicates an agenda for research. In particular, it illustrates the need to stimulate the learning orientations of less-qualified younger workers. A model for exploring the relationship between organisational environments and young workers' learning-related beliefs and attitudes is presented.
\end{abstract}

\section{Introduction}

Developing organisational and individual capability as a means of achieving economic competitiveness and growth have been recognised as key goals for New Zealand in the $21^{\text {st }}$ Century. Skilled employees are vital for New Zealand's economic growth and sustainability (Ministry of Economic Development, 2003). Since the late 1990s the New Zealand government has publicly committed itself to the sustainable growth of New Zealand in a variety of ways, including economic and social policy and providing funding for research and development in the area of innovation, growth and capability development.

\section{Capability Development}

In view of the need for skilled workers, there are concerns about persistent social and employment inequities for some groups. In particular, the shortage of workers with relevant vocational skills has serious implications for organisational growth. New Zealand's steady economic growth over the last decade has exacerbated the need for skilled workers, particularly in manufacturing, construction and other export-based industries (Business N.Z., 2001). Organisations are finding that workers are increasingly in need of, but often lacking, higher-order skills required for knowledge-based work, but also for the operation of technological-based machinery and work processes. The demand for highly skilled workers is a particular issue for small organisations who have higher demands for skill versatility and adaptability, but spend less on training (Berryman, 1994; Gorard, 2003). These higher order 'skills' are not strictly work-related skills, but include personal attributes such as reliability, initiative, respect for authority, work-related attitudes and behaviours including an interest in work and a work ethic, and learning-related attitudes such as a willingness to learn, trainability and adaptability (Comrie et al. 2005; Smith \& Comyn, 2004; Taylor, 2005).

Moreover, there are concerns at the high number of workers, including school leavers, with low levels of foundation skills required for current and future labour market performance (Bowers et al. 1999; Higgins, 2003). Basic skills, such as literacy, numeracy and communication, are fundamental to individual functioning in society and in the workplace, and are essential for organisational productivity. Like many industrialised countries, New Zealand has low literacy levels, posing a significant issue for organisations and increases the risk of poor labour market outcomes for individuals (Johnson, 2000). Studies show that low skills are strongly associated with low qualifications, low earnings, limited job and career prospects including opportunities for training (Ananiadou et al. 2003; Bowers et al. 1999; Bynner, 2002). It is also believed that those with low literacy will experience increasing difficulty in obtaining and retaining employment, and are at risk of becoming increasingly marginalised from society by being confined to precarious types of employment or marginal activities (Johnson, 2000). This is particularly concerning given the number of young people leaving school with minimal qualifications, both in New Zealand and overseas (Bowers et al. 1999; Statistics New Zealand, 200 lb). 
Despite some criticisms that adult education, particularly literacy and numeracy, does not necessarily improve economic and employment outcomes (Gorard, 2003; Treasury, 2001) and may in fact reduce job satisfaction and organisational commitment (Rose, 2005), there is growing evidence of the benefits to employers from improving employees' basic skills (see Ananiadou et al. 2003 for a comprehensive review). In particular, literacy training is believed to lead to gains in productivity, efficiency and economic competitiveness, directly (through time savings and reduced waste), and indirectly (through uptake of further training, improvements in staff morale, health and safety, interpersonal communication and customer retention) (Johnson, 2000). Literacy training is also credited with positive effects on worker attitudes toward their job, organisational satisfaction, self reported productivity, self esteem, and confidence in applying for and taking up new job responsibilities and promotions (Ananiadou et al. 2003). Recent findings from the Manukau Family Literacy Project revealed significant return on investment and increased earnings from improving adult literacy (PriceWaterhouseCoopers, 2006). Foundation skills are, unarguably, critical for effective social and workplace functioning, and addressing literacy needs is a key part of improving the skill levels in New Zealand: however. workers increasingly need higher order skills, including a willingness and ability for continual learning.

\section{Developing Lifelong Learners}

The need for workers to be active lifelong learners is paramount (New Zealand Government, 2001). Broadly defined, lifelong learning includes "all learning that enhances and contributes to knowledge and skills" (Pendergast et al. 2005), and is believed to help individuals develop skills and confidence enabling continued participation in work and society (Fryer. 1999). Researchers have sought to understand the extent to which capability is innate or learned. Although some extent of individual capacity is innate, it is believed much is learned, both formally and informally, through a variety of situations and environments (Department of Labour. 1999; New Zealand Government. 2001). Because capacity can diminish it is important for society and organisations to continually invest in the maintenance and development of individual and collective capacity both directly through skill development, and indirectly through enabling and encouraging individuals to grow and develop in organisational settings. Higher-order skills such as adaptability, flexibility, and a willingness to learn are clearly important in today's business environment, and the development of individual's orientation to learn at work can therefore be seen to contribute to a lifelong learning agenda.

Unfortunately, not all workers have equal access to vocational training or opportunities for workplace learning, potentially reinforcing disadvantage faced by some workers. Studies have found that low-qualified and low-skilled workers receive less training. development or promotion opportunities than their more qualified peers (CIPD, 2002; OECD, 1999; Rainbird, 2000; Rainbird et al. 1999). Consequently the role of managers as 'gatekeepers' of learning opportunities has received attention, with suggestions that some managers may regard training as a reward for high performance rather than a tool for skill improvement. It seems incongruous that workers who would benefit the most from training are often excluded from or unaware of such opportunities or, sadly, lack the self-confidence to engage in or pursue them (Fryer, 1999). These sentiments are shared by Bynner (2002) who suggests that lifelong learning is needed in order for all individuals to keep a foothold in the labour market.

\section{Young Workers}

In addressing the development needs of lower-skilled workers, researchers have also called for the need to develop the capabilities of young workers, particularly those from lower socioeconomic backgrounds and with low levels of qualifications and basic skills. In 2001, young people aged 15-24 comprised $13 \%$ of New Zealand's total population (approximately 505,000) (Statistics New Zealand, 2001a). This cohort has high levels of labour market participation $(64 \%)$, with almost $80^{\circ}$ of participants in some form of employment. Overall, young workers account for approximately $15 \%$ of the total employed labour force, and represent $25 \%$ of the part-time and $12 \%$ of the full-time labour force.

A closer look at the relationships between with educational achievement and outcomes reveals a number of patterns. Firstly, young workers tend to be employed in lower-skilled occupations, with $80 \%$ working as clerks, sales and service workers and in manual occupations (Statistics New Zealand, 2001a). While this may be a reflection of their high involvement in part-time work, it further questions the nature and quality of young people's work, much of which is 'precarious' (Tucker, 2002; WEB Research, 2004), with fewer opportunities for career development than permanent or more highly skilled occupations

Secondly, those with low or no qualifications experience higher levels of unemployment than those with some form of basic qualification. There is also concern that the requirement for higher levels of skills will increase the risk of job loss for the less-literate, and that such workers will continue to be overlooked for skill development (New Zealand Government, 2001). Although researchers have begun to examine the quality of young people's work, a better understanding of young workers experiences of work-based learning is important in developing a workforce that is skilled, adaptable and motivated to learn.

\section{Transition firom School to Work}

Young people have received special attention in policy and research agendas, most notably with the Youth Development Strategy in 2002. The Strategy (Ministry of Youth Affairs, 2002) outlines how government and society can support young people aged 12 to 24 years to develop the skills and attitudes they need to take part positively in society, both now and in the future. These 
years are seen as being critical for human development as they build on childhood experiences and set the foundations for adulthood. Others have also signified the importance of young people's labour market participation and outcomes (New Zealand Business Council for Sustainable Development, 2003). Consequently, researchers are investigating the nature of young people's post-school pathways and experiences in New Zealand (Steedman, 2004; Vaughan, 2003), and also Australia (Ball \& Lamb, 2001; McMillan \& Marks, 2003; Smith \& Green, 2005), the United Kingdom (Biggart, 2002) and the USA (Lamb \& Rumberger, 1999).

The transition from school to work or other activities is often characterised by moves in and out of the labour market, between occupations or employers, and some spells of unemployment. This time is often referred to as one of churning, turbulence or floundering (Gardecki \& Neumark, 1998). However, turbulence is often short lived, and the risks to labour market outcomes can be reduced by avoiding unemployment, receiving on the job training, or increasing qualifications (Biggart, 2002).

While many young people successfully navigate their way from school to work, and often independently, there are concerns about the numbers of young people leaving school with low or no formal qualifications (New Zealand Government, 2001), posing threats to the average skill level and adaptability of the labour force in the future. Approximately $19 \%$ of school leavers each year leave with no or low qualifications, and almost half $(42 \%)$ of all young people leave school before Year 13 (Statistics New Zealand, 200 lb). What is more, despite overall increases in tertiary enrolments, most students are studying at levels equivalent to senior school qualifications or basic vocational qualifications (Ministry of Education, 2005).

Concerns about the risks of poor transitions have resulted in an explosion of initiatives aimed at creating more stable movements from school to other activities (see Higgins, 2003 for a comprehensive review). A number of these target school leavers with low or no qualifications to improve their work and life skills and subsequent labour market outcomes (e.g. Training Opportunities, Youth Training), or provide school students with an opportunity to gain work experience and explore their career options (e.g. Gateway, STAR). Other initiatives include the Mayors Taskforce for Jobs, with the goal of having all 15-19 year olds into work, education or training by 2007; the Youth Employment Project, targeting youth at risk of not training or working, including school leavers with little or no school qualifications, unemployed or underemployed youth, and Maori and Pacifica youth (New Zealand Business Council for Sustainable Development, 2003); and the development of Youth Transition Services and One-Stop Transition Shops.

While indicators suggest many programmes are helping achieve smoother post-school transitions (e.g. Boyd \& McDowall, 2004; Skill New Zealand, 2002), little is known about the experiences of young people beyond their initial destination, or the experiences of those who independently transition into the workforce. The majority of studies have focused on the destinations or labour market outcomes of young workers after leaving school (McMillan \& Marks, 2003), or the experiences of adolescents also in compulsory or further education. Few researchers have explicitly examined the experiences of young workers for whom employment is their primary activity. In view of current capability and youth development agendas, research is needed to provide a better understanding of the experiences of young workers as they begin forming their working careers - in particular, their perceptions, attitudes and participation in learning at work.

\section{An 'Orientation to Learn'}

Research indicates that younger workers are generally more positive about learning (Maurer et al. 2003a) and more adaptable to change than older employees. According to Bloomer and Hodkinson (2000a; Bloomer \& Hodkinson, 2000b), learning careers are shaped by a range of life experiences and learning that occurs outside of formal education or training settings. Their study of adolescents aged 15 to 19 years showed that the personal identities of younger workers were significantly transformed during these years. However, younger workers also face a number of barriers to learning. In particular, family backgrounds provide important influences and access to modelled behaviours, aspirations, and access to information and opportunities, and are important predictors of adolescent outcomes (Ali et al. 2005; Caspi et al. 1998; Johnson, 2002; Steinberg \& Sheffield-Morris, 2001).

Learners also face barriers in organisational settings when excluded from opportunities for learning and development. Exclusion from developmental opportunities is a particular issue for workers in lower skilled. part-time or precarious employment (CIPD, 2002; Tucker, 2002; WEB Research, 2004). Dispositional factors can also act as barriers to learning. In the context of adult learning, negative perceptions of learning ability, confidence, self esteem and anxiety can act as barriers to participation (Culligan, 2005). Another study found that for participants of adult education, schooling was perceived as a 'disabling experience', and reinforced internal beliefs about learning qualities reducing intentions to participate in further education (MacLachlan \& Cloonan, 2003 cited in Culligan, 2005).

Poor experiences of learning can have potentially damaging effects on an individual's beliefs about their ability to learn or the value of learning, and may reinforce or generate negative attitudes towards participation in learning at work. Thus it is conceivable that young adults who leave school early or with few qualifications may have had poor learning experiences in the formal schooling system. The importance of outcome expectancies is also important in understanding learning motivation (Colquitt et al. 2000).

In an attempt to integrate numerous learning-related concepts, Maurer (Maurer, 2002) proposed a model describing an 'employee learning and development orientation'. This orientation, referred to here as an 
'orientation to learn', is described as a motivational state whereby an individual has a tendency to learn and develop, in so far as learning is seen to be relevant to the individual. The model draws on foundational theories of vocational behaviour including Social Cognitive Career Theory (Lent et al. 1994) and the Theory of Planned Behaviour (Ajzen, 1991). An employee's learning and development orientation incorporates cognitive, affective and behavioural components, including dispositional traits and more malleable attitudes and beliefs. In particular Maurer draws attention to the need to examine the role of organisational environments in relation to employees' tendency to learn in work settings. Maurer and colleagues (Maurer et al. 2003a) have subsequently examined relationships between a number of individual and situational variables in predicting work-related developmental activity. Their results indicate that an employee who is orientated towards development has participated in prior developmental activities, perceives themselves as being able to learn, has support for development both at and away from work, has insight into their career and need for development, and values intrinsic outcomes.

In attempting to determine differential predictors of organisational outcomes, researchers have examined a number of dispositional traits including conscientiousness, neuroticism and goal orientation. Judge and colleagues (Judge et al. 2003; Judge et al. 2002) recently developed the Core Self Evaluation Scale (CSES), a measure of four strongly-related traits - self esteem. neuroticism, locus of control and general self efficacy. Subsequent studies have found that CSEs are distinct from other dispositional traits (e.g. conscientiousness and openness), and are positively associated with job satisfaction. organisational commitment (Judge et al. 2003), perceptions of organisational support and perceptions of investment in employee development (Pajo et al. 2005a).

Other researchers have examined the role of dispositional goal orientations in relation to employee learning and organisational outcomes (Martocchio \& Hertenstein. 2003: Pajo et al. 2005b: Potosky \& Ramakrishna, 2002). One study found that learning goal orientation was not, as predicted, related to work-related development intentions. but that a positive climate for employee development was more strongly associated with the outcomes studied (Pajo et al. 2005b). Openness to experience (OTE) has received less attention in relation to workplace learning. but may be potentially important in understanding employees orientation to learn and career success (Lounsbury et al. 2003). Dispositional traits are clearly important predictors of vocational behaviours, and may provide a better understanding of the relationships between organisational learning environments and employee learning orientations

\section{Organisational Learning Enviromments}

In examining organisational environments, researchers distinguish between psychological climates and organisational climates. Psychological climates are individual-level perceptions of specific organisational characteristics, while the latter are an aggregated measure of individual climates for a specific work group or entire organisation (Parker et al. 2003; Patterson et al. 2004). Measures of specific learning-related climates include perceptions of organisational support (Rhoades \& Eisenberger, 2002), organisational support for learning and development (Lee \& Bruvold, 2003), supervisor support (Eisenberger et al. 2002; Maurer et al. 2003a), and peer support. These climates provide important insights into a range of workplace behaviours and outcomes, including attitudes towards learning, job satisfaction and organisational commitment.

Studies examining young people's experiences of work have historically tended to focus on work quantity, but more recently have signalled the potential importance of work quality for young workers (Loughlin \& Barling, 2001). Work quantity has been examined in relation to school achievement, career interests, and the formation of work values (Johnson, 2002; Shanahan et al. 2002). Measures of adolescent work quality have included job status, earnings, job characteristics (including skill variety, autonomy, skill utilisation and opportunities to learn) role stressors (ambiguity, conflict, overload) and interpersonal relationships (Johri, 2005; Loughlin \& Barling, 1998: O’Brien \& Feather, 1990; Stern et al. 1990). No studies appear to have specifically examined young workers' perceptions of organisational learning environments. Including such measures in future rescarch may offer new insight about the quality of young people's work environments.

By providing opportunities and support for learning at work, organisations may be able to positively influence individuals beliefs and attitudes about, and experiences of learning. Individuals who believe they can learn, see the value of learning, and are encouraged to learn at work are more likely to be interested and engaged in learning. If an employee's orientation to learn can be enhanced through a positive learning climate, other outcomes (such as job satisfaction and organisational commitment) may also be expected. Accordingly, organisational environments may be potentially important places for the development of young people's identities of themselves as learners

\section{Proposed Research}

Given the importance of developing capability of all levels of employees, a more robust understanding is needed of the experiences and characteristics of those who will be the future labour market - that is young workers. A model for examining young workers' orientation to learn in the context of their organisational environments is proposed, which forms the basis of the author's current doctoral research (See Figure 1). 




This research will examine the experiences of (primarily) vocationally-skilled young workers (aged 16-24) in order to identify the relationship between organisational learning climates and individual's orientation to learn. Specifically:

- What are young workers perceptions of organisational learning climates?

- How are organisational climate perceptions related to learning-related attitudes \& beliefs, affective (organisational) outcomes, participation in workrelated developmental activities, and intentions to participate in developmental activities?

- To what extent do individual differences (e.g. socioeconomic status, school leaving age, dispositional traits) influence these attitudes, beliefs and behaviours?

Three phases of data collection are proposed. Using semi-structured interviews, the first phase will explore the understanding of a number of young workers about various learning-related concepts that will inform questionnaire development. The second and central phase of the research comprises a cross-sectional survey to measure a number of learning-related beliefs, attitudes and experiences of young workers. The third and final phase of the research will use in-depth interviews with a small number of young workers to gain a better understanding of their experiences of learning at work.

\section{Limitations and Considerations}

There are a number of potential limitations relating to the proposed method - specifically literacy, individual motivation, and availability. Thus survey questions need to be easy to understand by respondents who may have low literacy levels. In addressing motivation, particularly for young workers who have had poor experiences of prior learning, and availability, the researcher proposes to provide survey completion support to participants, via their organisations, using small-group settings; a drop-off and pick-up method; and where necessary a drop-off and mail return method. The most significant limitation is the voluminous number of interrelated variables relevant to a learning orientation. An attempt to measure and/or control for all such variables is, in a word, impossible. Consequently this research proposes to limit its focus to those most relevant to the stability and malleability of young workers' orientation to learn. It is hoped that identifying the existence and strength of hypothesised relationships will contribute a foundation for future longitudinal studies.

\section{Conclusion}

This paper has reviewed New Zealand and international literature relevant to understanding the development of young adults as they enter the labour market as full-time participants. Previous research has established important relationships that explain the nature and outcomes of learning at work; however few studies have paid attention to the learning experiences of young workers in the labour market, or the potential impact of learning environments on their orientation to learn. Given the importance of this group of workers to future organisational and economic growth, it is imperative we develop a more robust understanding of the nature of their experiences of work-based learning. Identifying the potential impact of organisational environments on employees' attitudes and beliefs about learning may provide an important step toward developing adaptable, 
learning-focused and skilled workers required for the future.

\section{References}

Ajzen, I. (1991). The theory of planned behaviour. Organizational Behavior and Human Decision Processes, 50, 179-211.

Ali, S.R., McWhirter, E.H. and Chronister, K.M. (2005). Self-efficacy and vocational outcome expectations for adolescents of lower socioeconomic status: A pilot study. Journal of Career Assessment, 13(1), 40-58.

Ananiadou, K., Jenkins, A. and Wolf, A. (2003). The Benefits to Emplovers of Raising Workforce Basic Skills Levels: A Review of the Literature. London: National Research and Development Centre for Adult Literacy and Numeracy.

Ball, K. and Lamb, S. (2001). School non-completers: Outcomes in vocational education and training. Paper presented at the Australian Vocational Education and Training Research Association Conference, 28-30 March, Adelaide, South Australia.

Berryman, S.E. (1994). The Role of Literacy in the Wealth of Individuals and Nations. Retrieved 12 November, 2006, from http://eric.ed.gov/ERICDocs/data/ericdocs2/cont ent_storage_0l/0000000b/80/22/75/dl.pdf

Biggart, A. (2002). Attainment, gender and minimumaged school leavers' early routes in the labour market. Journal of Education and Work, 15(2). 145-162.

Bloomer, M. and Hodkinson, P. (2000a). Learning careers: Continuity and change in young people's dispositions to learning. British Educational Research Journal, 26(5), 583-597.

Bloomer, M. and Hodkinson, P. (2000b). The complexity and unpredictability of young people's learning careers. Edlucation and Training. 42(2), 68-74.

Bowers, N., Sonnet, A. and Bardone, L. (1999). Giving Young People a Good Start: The Experience of OECD Countries. Paris: OECD Secretariat.

Boyd, S. and McDowall, S. (2004). Innovative pathways from secondary school: Where are the young people now? Paper presented at the NZARE Conference. 24-26 November 2004. Wellington.

Business N.Z. (2001). Skill Shortages and De'relopment Discussion Paper. Wellington: Business NZ.

Bynner, J. (2002). Literacy, numeracy and employability. Adult Literacy and Numerace.
Australian Research Consortium (ALNARC) OnLine Forumfunded, Retrieved 12 November, 2006 from

http://www.staff.vu.edu.au/alnarc/onlineforum /AL_pap_bynner_word.doc

Caspi, A., Wright, B.R.E., Moffitt, T.E. and Silva, P.A. (1998). Early failure in the labor market: Childhood and adolescent predictors of unemployment in the transition to adulthood. American Sociological Review, 63(3), 424-451.

Chartered Institute of Personnel Development (CIPD). (2002). Who Learns at Work? (Survey Report). London: CIPD.

Colquitt, J.A., LePine, J.A. and Noe, R.A. (2000). Toward an integrative theory of training motivation: A meta-analytic path analysis of $\mathbf{2 0}$ years of research. Journal of Applied Psichology: 85(5), 678-707.

Comrie, M., Olsson, S., Sligo, F., Culligan, N., Tilley, E., Vaccarino, F. and Franklin, J. (2005). Perceptions. Needs and Issues: A Discussion Paper. No. 0502. Palmerston North: Massey University.

Culligan, N. (2005). Theoretical Understandings of Adult Literacy: A Literature Review. Palmerston North: Massey University.

Department of Labour (1999). Human Capability - A Framework for Analysis. Wellington: Department of Labour.

Eisenberger, R., Stinglhamber, F., Vandenberghe, C., Sucharski, I. and Rhoades, L. (2002). Perceived supervisor support: Contributions to perceived organizational support and employee retention. Journal of Applied Psychology, 87(3), $565-573$.

Fryer, R.H. (1999). Creating learning cultures: Next steps in achieving the learning age. Second Report of the National Advisory Group for Comtiming Education and Lifelong Learning Retrieved 12 November 2006, from http:/www.lifelonglearning.co.uk/nagcell2 nagcell2.pdf

Gardecki, R. and Neumark, D. (1998). Order from chaos? The effects of early labor market experiences on adult labor market outcomes. Industrial and Labor Relations Review, 51(2), 299-322.

Gorard, S. (2003). Patterns of work-based learning. Journal of locational Education and Training. $55(1), 47-64$.

Higgins, J. (2003). Labour Market Programmes for Young People: A Review. Wellington: Ministry of Social Development. 
Johnson, A.H. (2000). Changing Skills for a Changing World - Recommendations for Adult Literacy Policy in Aotearoa/New Zealand. Wellington: Department of Labour.

Johnson, M.K. (2002). Social origin, adolescent experiences, and work value trajectories during the transition to adulthood. Social Forces, 80(4), 1307-1341.

Johri, R. (2005). Work Values and the Quality of Employment: A Literature Review. Wellington: Department of Labour.

Judge, T., Bono, J. and Thoresen, C. (2003). The core self-evaluations scale: Development of a measure. Personnel Psychology, 56(2), 303-332.

Judge, T., Erez, A., Bono, J. and Thoresen, C. (2002). Are measures of self-esteem, neuroticism, locus of control, and generalized self-efficacy indicators of a common core construct. Journal of Personality and Social Psychology, 83(3), 693-710.

Lamb, S. and Rumberger, R. (1999). The Initial Education and Labour Market Outcomes of Early School Leavers: A Comparative Study of Australia and the United States. LSAY Research Report No. 14, Department of Education, Science and Training.

Lee, C.H. and Bruvold, N.T. (2003). Creating value for employees: Investment in employee development. International Journal of Human Resource Management, 14(6), 981-1000.

Lent, R.W., Brown, S.D. and Hackett, G. (1994). Toward a unifying social cognitive theory of career and academic interest, choice, and performance. Journal of Vocational Behavior. 45(1), 79-122.

Loughlin, C. A. and Barling, J. (1998). Teenagers' parttime employment and their work-related attitudes and aspirations. Journal of Organizational Behavior, 19(2), 197-207.

Loughlin, C. A. and Barling, J. (2001). Young workers' work values, attitudes, and behaviours. Journal of Occupational and Organizational Psychologv. 74, 543-558.

Lounsbury, J.W., Loveland, J.M., Sundstrom, E.D., Gibson, L.W., Drost, A.W. and Hamrick, F.L. (2003). An investigation of personality traits in relation to career satisfaction. Journal of Career Assessment, 11(3), 287-307.

Martocchio, J.J. and Hertenstein, E.J. (2003). Learning orientation and goal orientation context: Relationships with cognitive and affective learning outcomes. Human Resource Development Quarterly, 14(4), 413-434.
Maurer, T.J. (2002). Employee learning and development orientation: Toward an integrative model of involvement in continuous learning. Human Resource Development Review, 1(1), 944.

Maurer, T.J., Weiss, E.M. and Barbeite, F.G. (2003). A model of involvement in work-related learning and development activity: The effects of individual, situational, motivational, and age variables. Journal of Applied Psychology, 88(4), 707-724.

McMillan, J. and Marks, G.N. (2003). School Leavers in Australia: Profiles and Pathways. LSAY Research Report No. 31. Camberwell, Victoria: Department of Education, Science and Training.

Ministry of Economic Development (2003). Growth and Innovation Framework. Wellington: Ministry of Economic Development.

Ministry of Education (2005). Education Counts. Retrieved I November, 2006, from http://educationcounts.edcentre.govt.nz/publicati ons/homepages/education-statistics/ed-stats $-2005 . h t m l$

Ministry of Youth Affairs (2002). Youth Development Strategy Aotearoa. Wellington: Ministry of Youth Affairs.

New Zealand Business Council for Sustainable Development (2003). Business Guide to Youth Employment. Auckland: New Zealand Business Council for Sustainable Development

New Zealand Government (2001). Workforce 2010. Wellington: New Zealand Government.

O'Brien, G. and Feather, N. (1990). The relative effects of unemployment and quality of employment on the affect, work values and personal control of adolescents. Journal of Occupational Psychology, 63(2), 151-165.

OECD (1999). Training of Adult Workers in OECD Countries: Measurement and Analysis: OECD.

Pajo, K., Guenole, N., Mallon, M. and Ward, R. (2005). The Impact of Core Self-Evaluations on Perceptions of Support, Commitment, and RoleConflict. Paper presented at the Academy of Management, Hawaii. 5-10 August 2005.

Pajo, K., Ward, R. and Mallon, M. (2005). The Impact of Individual Goal Orientation and Perceptions of Support for Emplovee Development on WorkRelated Outcomes. Paper presented at the Researching Work and Learning 5, Australia.

Parker, C.P., Baltes, B.B., Young, S.A., Huff, J.W., Altmann, R.A., Lacost, H.A. and Roberts, J.E. (2003). Relationships between 
psychological climate perceptions and work outcomes: A meta-analytic review. Journal of Organizational Behavior, 24(4), 389-416.

Patterson, M., Warr, P., and West, M. (2004), Organizational climate and company productivity: The role of employee affect and employee level. Journal of Occupational and Organizational Psychology. 77, 193-216.

Pendergast, D., Flanagan, R., Land, R., Bahr, M., Mitchell, J., Weir, K., Noblett, G., Cain, M., Misich, T., Carrington, V. and Smith, J. (2005). Developing Lifelong Learners in the Middle Years of Schooling: School of Education. University of Queensland.

Potosky, D. and Ramakrishna, H.V. (2002). The moderating role of updating climate perceptions in the relationship between goal orientation, selfefficacy, and job performance. Human Performance, 15(3), 275-297.

PriceWaterhouseCoopers (2006). Comet: Manukau family literacy programme outcomes valuation project. Retrieved 8 November, 2006, from http://comet.org.nz/documents/MFLPOutcomes ValuationReport-Public Copy.pdf

Rainbird, H. (2000). Skilling the unskilled: Access to work-based learning and the lifelong learning agenda. Journal of Echucution and Work. 13(2). 183-197.

Rainbird, H., Munro, A., Holly, L., and Leisten, R. (1999). The Future of Work in the Public Sector: Learning and Workplace Inequalits: Northampton: Centre for Research in Employment. Work and Training.

Rhoades, L. and Eisenberger, R. (2002). Perceived organizational support: A review of the literature. Journal of Applied Psicholegr: 87(4). $698-714$

Rose, M. (2005). Do rising levels of qualification alter work ethic, work orientation and organizational commitment for the worse? Evidence from the UK, 1985-2001. Journal of Educution and It ork. $18(2), 131-164$

Shanahan, M.J., Mortimer, J.T., and Kruger, H. (2002). Adolescence and adult work in the twenty-first century. Journal of Research on Adolescence, 12(1), 99-120.

Skill New Zealand (2002). Building Futures: The Final Report on the Review of Training Opportunities and Youth Training. Wellington: Skill New Zealand.

Smith, E. and Comyn, P. (2004). The role of employers in the development of employability skills in novice workers. Research in Post-Compulsory Education, 9(3), 319-336.

Smith, E. and Green, A. (2005). How workplace experiences while at school affect career pathways. Adelaide: National Centre for Vocational Education Research (NCVER).

Statistics New Zealand (2001a). 2001 Census: Work. Wellington: Statistics New Zealand.

Statistics New Zealand (200lb). School Leavers with no Qualifications. Wellington: Statistics New Zealand.

Steedman, S. (2004). Aspirations of Rurally Disadvantaged Maori Youth for their Transition from Secondary School to Further Education or Training and Work. Wellington: Department of Labour.

Steinberg, L., and Sheffield-Morris, A. (2001). Adolescent development. Annual Review of Psichologi: 52(1), 83.

Stern, D., Stone, J. R., II, Hopkins, C. and McMillion, M. (1990). Quality of student's work experience and orientation toward work. Youth \& Society. 22(2), 263-282

Taylor, A. (2005). What employers look for: The skills debate and the fit with youth perceptions. Jounal of Education and Work, 18(2), 201-218.

Treasury (2001). Human Capital and the Inclusive Econom!: Wellington: New Zealand Treasury.

Tucker, D. (2002). "Precarious" Non-Standard Emplosment - A Review of the Literature. Wellington: Department of Labour.

Vaughan, K. (2003). Changing Lanes: Young People Making Sense of Pathwavs. Paper presented at the NZCER Annual Conference - Educating for the 21st Century: Rethinking the educational outcomes we want for young New Zealanders, Wellington

WEB Research (2004). Report of Exploratory Case Stucty Research into Precarious Employment. Wellington: Centre for Research on Work, Education and Research Limited.

\section{Author}

Robyn Mason

Assistant Lecturer

Department of Human Resource Management

Massey University

P.O. Box 11222

Palmerston North

R.L.Mason(a massey.ac.nz 